\title{
MAPPING LEGAL THEORY
}

\author{
RICHARD F. DEVLIN*
}

In this essay, the author briefly outlines recent trends in Canadian jurisprudence. Beginning with a brief overview of the classical jurisprudential debate between natural lawyers, legal positivists, and legal realists, the author then provides an introduction to a new theoretical tradition which he terms "Artifactualism", as well as a survey of contemporary "Artifactualist Jurisprudence". He argues that there has been a significant theoretical shift away from the classical conceptualization of law as morality (as embodied in natural law, and challenged by legal positivism and legal realism), toward the conceptualization of law as politics (as promulgated by artifactualism). This new conceptualization of law as the "terrain of struggle over the meaning and quality of social existence" has informed the works of Artifactualist jurisprudents in the areas of Liberalism, Marxism, Feminism, First Nations and Critical Legal Studies, and serves to elucidate some of the tensions in the Canadian Charter of Rights and Freedoms.
Dans le présent essai, l'auteur décrit rapidement les tendances récentes de la science juridique canadienne. Il commence par un bref survol du débat jurisprudentiel classique opposant les avocats naturels, ceux qui se classent parmi les positivistes et les réalistes. L'auteur présente ensuite une nouvelle tradition théorique qu'il qualifie d' «artefactualisme», et passe en revue la science du droit artéfactuelle contemporaine. Il soutient que la théorie s'écarte notablement de la conceptualisation classique du droit en tant que moralité (incarné par le droit naturel et remis en question par le positivisme et le réalisme juridique), pour évoluer vers la conceptualisation du droit en tant que politique (ce que promulgue l'artéfactualisme). Cette nouvelle conceptualisation, qui fait du droit aun champ de bataille sur le sens et la qualité de l'existence socialen, inspire les travaux des juristes artéfactualistes qui se penchent sur le libéralisme, le marxisme, le féminisme, les premières nations, ainsi que les études de droit critique. Elle sert à élucider certaines des tensions présentes dans la Charte canadienne des droits et libertés.

\section{TABLE OF CONTENTS}

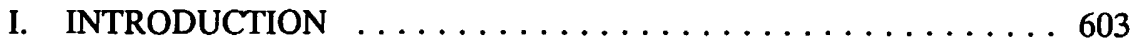

II. A BRIEF HISTORY OF

JURISPRUDENTIAL TIME $\ldots \ldots \ldots \ldots \ldots \ldots \ldots \ldots \ldots 64$

A. THE NATURAL LAW TRADITION $\ldots \ldots \ldots \ldots \ldots \ldots 604$

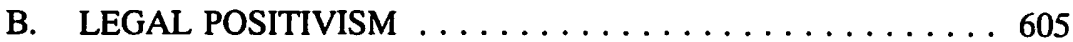

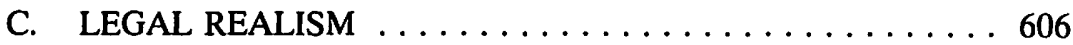

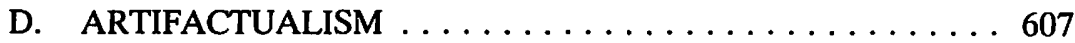

III. ARTIFACTUALISM AND THE PERSPECTIVES . . . . . . . 609

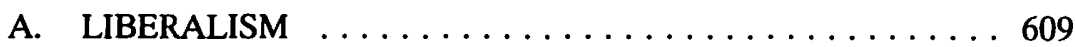

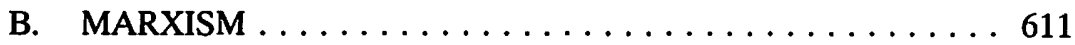

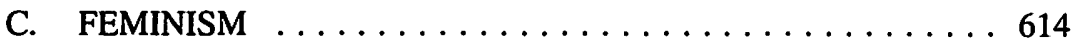

D. FIRST NATIONS $\ldots \ldots \ldots \ldots \ldots \ldots \ldots \ldots \ldots \ldots 616$

E. CRITICAL LEGAL STUDIES $\ldots \ldots \ldots \ldots \ldots \ldots \ldots \ldots 6$

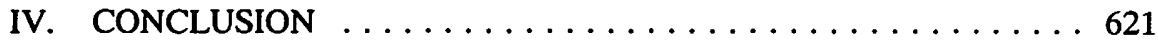

Formerly of the Faculty of Law, the University of Calgary; currently of Dalhousie Law School. I would like to express my gratitude to Alexandra Dobrowolsky for her comments on a draft of this essay. 


\section{INTRODUCTION}

For some, an essay on legal theory may appear to be an interloper in a book that has the pragmatic question of legal developments in particular doctrinal areas over the last twenty-five years as its primary focus. However, two aspects of my own experience suggest to me that it is important to raise jurisprudential questions in a forum that has legal practitioners as its principal target market. The first is that, as a teacher for some six years, I continually find myself perturbed by the phenomenon that many first year students appear to have a wealth of experience to draw upon when they arrive at law school, but lose so much of that as they proceed through what the professoriate, perhaps rather grandiosely, calls "the academic program". Legal education as a discipline, I would argue, is viciously disciplinary in that it aspires to exclude and render irrelevant other viewpoints. The focus on formalistic rules and instrumentalist skills means that the talent of critical thinking is, by and large, underdeveloped in the law schools. ${ }^{1}$

My second point also relates to this tendency towards the closing of the legal mind. When I have discussions with some of my former students or current practitioner-friends about the nature of the problems they encounter in practice, or even about some of the larger legal issues that preoccupy the public agenda, I am always disturbed by the narrow conceptualization of the issues. To be clear, my suggestion is not that such people are not very bright. Rather, it is that their imaginative horizons appear to be so curtailed by their conceptual framework that alternative conceptualizations appear to be simply unintelligible, essentially "non-questions". ${ }^{2}$ "Black letterism" as an ideology curtails their frameworks of analysis. ${ }^{3}$

Perhaps an example may help. On several occasions over the last few years I have found myself in situations where members of the judiciary and I were embarked upon an intensive inquiry into a series of issues that necessarily required reflection on the nature and function of law in contemporary Canadian society. One of the most frustrating aspects of this experience was endeavouring to have these judges even go through the process of attempting to consider the importance of reflection on the primary jurisprudential question, namely, the nature and function of Canada's current legal system. For them it seemed too elemental, too taken for granted to merit analysis.

In this essay, I wish to attempt to bridge this void between those who practice legal theory in the academy, and those who practice legal practice, be they lawyers or judges. My analysis is composed of two parts. First, I shall trace a very brief history of jurisprudential time, highlighting the legal theoretical traditions of Natural Law, Legal Positivism and Legal Realism. Second, I will demonstrate how these traditions have been

For an elaboration of these ideas, see R.F. Devlin, "The Commitment: Deviating with Private Law" [unpublished].

J. McCalla Vickers, "Memoirs of an Ontological Exile" in A. Miles \& G. Finn, eds., Feminism in Canada: From Pressure to Politics (Montreal: Black Rose Books, 1989) 37.

For one example of such a myopic viewpoint see D. Watson, "Is Legal Scholarship Failing?" (1991)

15:1 Can. Law. 20. 
eclipsed by the emergence of a new legal paradigm that I will call "Artifactualism". ${ }^{4}$ On this foundation, I will emphasize aspects of the perspectives of some of the major players in the debates within this new interpretive framework of "Artifactual Jurisprudence" including: Liberalism, Marxism, Feminism, First Nations perspectives and Critical Legal Studies. My own perspective is an amalgam of several of these, but is most closely indentified with the last grouping.

My aim is extremely modest. It is simply to provide a map so that lawyers can better understand the terrain of social, political and philosophical debate in which law and legal practice inevitably find themselves - woods and trees and all that sort of stuff.

\section{A BRIEF HISTORY OF JURISPRUDENTIAL TIME}

In this section, I propose to develop a concise historical overview of the dominant traditions of legal theory in order to set the context for a better understanding of contemporary analyses. Within the framework of analysis that I wish to provide, the four major jurisprudential strands of legal philosophy are: Natural Law, Legal Positivism, Legal Realism, and Artifactualism. My purpose is merely to highlight the key components of each perspective and therefore, unfortunately, to underplay the vitally important debates that go on within each. The general proposition is that as jurisprudence has shifted from Naturalism, through Positivism and Realism to Artifactualism, there has been a "denaturalization" process whereby law is no longer seen as transcendental, somehow "out there" and autonomous of human activity. Rather, there is an increasing recognition that law is no more than a human construct, an artifact of human agency, contingent, socially and historically located, and (perhaps most importantly) therefore capable of renovation. Consequently, those affected by and involved with law can no longer claim that law is part of the natural order, beyond their control. Rather, this denaturalization process highlights the centrality of human action and the responsibilities that go along with such power. $^{s}$

\section{A. THE NATURAL LAW TRADITION}

The Natural Law tradition stretches back at least two thousand years to Greek philosophers and has been continually revised up to the present day. Whether it is Natural Law in its pagan rationalistic forms (Greek and Roman), or Christian divinic forms (St. Augustine and Aquinas), or its secularized, social contractarian and rights-based forms (Hobbes and Locke), several key themes unite these otherwise very diverse jurists. First, Natural Law claims to be universal, immutable, eternal, objective, and beyond any particularized political or historical context. Natural Law thinking is the quest for absolute values, justice and truth. Second, Natural Lawyers propose that the validity of any law depends on its content, not just its form. There is an integral relationship between law and

These ideas of "Artifactualism" and "Artifactual Jurisprudence" are inspired, in part, by the social theory of R.M. Unger, Politics (England: Cambridge University Press, 1987).

This "denaturalization thesis" is derived in part from the ideas of "postmodernism". For a further articulation of both of these concepts see R.F. Devlin, "Reconstituting the Irish Hunger Strike as a Legal Claim: Postmodernism Meets Irish Republicanism" (forthcoming). 
morality. Third, Natural Law is said to be superior to human law and therefore has the justificatory and censorial power to determine whether enacted (i.e. positive) laws are morally binding.

Beyond these three themes, Natural Lawyers claim that their theory provides the best explanation for an obligation to obey the law. It provides both moral and legal arguments for obedience because a law is valid only if it is in accordance with "right reason". Such law has an intrinsic value independent of the ends it achieves and it need not be justified according to its utility. Natural Law is portrayed as the symbolic representation of justice and thereby encourages us to pursue "the good". Natural Lawyers argue that law and justice can never be separated, because to do so will result in a legal formalism that can be conducive to, for example, Nazi laws.

A variety of criticisms have undercut the validity and vitality of Natural Law theory. First, it is argued that this theory is not as universal as it claims to be. Attention has been focused on its mostly Roman Catholic presuppositions, and Natural Law theory has been accused of being an assertion of faith in a particular set of values rather than a demonstration of the truth of such values. Second, it is said that Natural Law is inherently ambiguous and no variation has ever provided a clear set of principles which could effectively guide or constrain positive (i.e. human made) law. Because of its refusal to take account of the reality of historical, empirical, scientific, anthropological and other factors, it is said by critics to be much too general, abstract and vague to offer any really practicable legal solutions in the face of any detailed and definite set of facts. A closely related third criticism is the malleability of Natural Law. At different times in different places, it has played conservative, liberal and even revolutionary roles. Natural Law is all things to all people - depending upon their own ideological bent. Fourth, sceptics posit that there is no rational way to know objectively what is right and what is wrong, and, as such, Natural Law propositions are necessarily relative, personal and subjective. No amount of information about human nature provides proof that anything ought or ought not to be done as a consequence. As Hume pointed out, you cannot derive "an ought" proposition from an "is" proposition. ${ }^{6}$ Finally, the critics argue that merging law with moral criteria causes confusion in our attempts to understand what law is.

\section{B. LEGAL POSITIVISM}

Positivism is both more recent than, and a reaction against, Natural Law theory. Hints of Positivism can be identified in the work of Hobbes, Locke and Hume, but it was not until the writings of Bentham and Austin in the nineteenth century, and those of H.L.A. Hart and Kelsen in the twentieth century, that it came into its own as a jurisprudential movement. Positivism wants to provide an analytical approach that allows us to know what law "is". Consequently, it seeks to keep the question of "what law is" distinct from the question of "what law ought to be," proposing that no reference to extrinsic factors such as justice or morality should enter into the definition of law. Positivism is driven by a quest for conceptual clarity and order. It aspires to be a scientific account of law. While 
few Positivists deny the importance of morality as an external criterion by which to assess any particular law, they nevertheless seek a temporary exclusion of morality so that law sui generis may be better understood.

After rejecting Natural Law's reliance on moralism, Positivists embraced empiricism: the belief that the essence of law could be discovered by empirical methodologies. This was an important breakthrough because it recognized that law is the product of human action and not merely the embodiment of some greater authority. Positivism saw law as essentially a system of rules and/or commands that generate habitual obedience. However, although Positivism reoriented legal philosophy and factored in human agency, its scientific pretensions meant that it did not take human agency seriously enough. Positivism stressed the structural processes that it believed underpinned people's relations but did not analyze the behaviour of the actual humans involved. This approach culminated in Hans Kelsen's self proclaimed Pure Theory of Law, which sought to purge analyses of law from what were seen as the contaminating influences of politics, ethics, sociology and history.

Positivism has had, and continues to have, a profound influence on legal thought in Canada. ${ }^{8}$ It is the primary philosophy relied upon by those who argue that law is still relatively autonomous from other social forces such as politics, economics, gender and race. These factors are rarely, if ever, incorporated into Positivistic inquiries of law. So, while human agency is acknowledged, no real attention is focused on the consequences of such agency for law. This has generated some criticisms of Positivism. First, it is accused of creating an ideology in which the validity of a law becomes its own moral criterion (usually called formalism) and this can lead to very unjust legal systems. Second, it is argued that Positivism's attempt to isolate law from its social, economic and political context to treat law as an object of scientific study, is an inappropriate extension of the methodologies of natural science. It is difficult even to identify, let alone study, the institutions and the actors who make up the legal system without also considering their context. and function.

\section{LEGAL REALISM}

Realism is a thoroughly modernistic phenomenon, surfacing in different forms in both Scandinavia and the United States in the early part of this century. To consider the North American version, American Realism was the product of a relatively small group of progressive scholars and judges whose pragmatism drove them to reject both the moralism of the Naturalists and the "arid conceptualism" of the Positivists. Thus, for example, Oliver Wendell Holmes posited that "the life of the law has not been logic, but experience. ${ }^{19}$ Realism sought to factor in some of those very elements of human agency that Positivism strove to marginalize.

7 (California: University of California Press, 1934).

8 For an important discussion of the influences of both natural law and legal positivism in the early years of the Canadian legal community see G.B. Baker, "The Reconstitution of Upper Canadian Legal Thought in the Late Victorian Empire" (1985) 7 L. \& Hist. Rev. 219.

O.W. Holmes, The Common Law (Boston: Little Brown, 1963) at 1. 
Realism sees law not as an object, but as part of a larger system which is always in flux. Consequently, Realism tends to see law as a means to achieve some social end. Therefore, it adopts a functionalist approach which inquires into both the purpose and effects of law. Realism, more so than Positivism, sees any analytical separation of "is" and "ought" as purely heuristic and admits that values have an unavoidable impact upon legal rules. As against Positivism, Realism is sceptical as to the centrality of rules within the legal system. It argues that rules are both much less determinative than Positivists assume and frequently irrelevant to an explanation of what actually happens when legal decisions are made. Realism also casts doubt on the judicial rhetoric which claims that judging is politically neutral because judges are simply following the rules. As a result, Realism encourages us to look behind the rules to see what the judges are actually doing as opposed to what they say they are doing. Specifically, Realists encourage us to inquire into the personalities, prejudices, political sympathies, economic preferences, idiosyncrasies and other "non-rational" factors that affect actors within the legal system. Furthermore, if this inquiry into what is actually happening in the legal system is to be seriously pursued, then Realism demands that we draw upon disciplines outside of law to help us better understand law (sociology, economics, psychology, criminology, etc.). Finally, Realism suggests that there is a great deal more to law than simply looking at what the courts do. Law is part of a broader social system and has many dimensions beyond the judicial decisions.

The impact of Realism in the United States, but not so much in Canada, has been quite pervasive, so that many lawyers claim "we are all Realists now." First, Realism has inspired important research in the non-rule governed aspects of our legal system such as the personal background of judges, the actual working of the jury system, the practical importance of the availability of legal representation, etc. Second, as against the Positivists, Realists have highlighted the indeterminacy of rules and their diminishing centrality within the legal system. Third, the interdisciplinary impulse generated by Realism demonstrates the necessarily contextual and local nature of law-making, thereby stressing the importance of the actual individuals involved and their social complexity.

Realism, not surprisingly, has its detractors. Positivists claim that Realists underplay the importance of rules and Natural Lawyers accuse them of instrumentalist social engineering, devoid of any conception of "the good". Artifactualism extends the critique, as will become obvious in the next section.

\section{ARTIFACTUALISM}

As a theory of law, Artifactualism builds upon the insights of Natural Law, Legal Positivism and Realism; at the same time, it criticizes these other theories. In common with Natural Law, Artifactualism recognizes that it is impossible to conceive of law without reference to the social values reflected in, and enforced by, law. However, according to Artifactualism, there is nothing separate or "out there" about law. What is universal, a priori, determinative and transhistorical to the Natural Lawyer, is contingent, historical, specific and local to the Artifactualist. So Artifactualists join with Legal Positivists in emphasizing that law is a human construct and that the focus should be on the more tangible dimensions of law. However, Artifactualists critique Legal Positivists 
for focusing their quest on the essence of law, and for not pushing the agency analysis to its obvious conclusion: contextual analyses of what people actually do through law. It is argued that Positivists factor out just those aspects of human agency Artifactualists find to be of crucial significance, issues such as race, class and gender, for example.

Moreover, the Positivistic quest for the essence of law in one sense echoes the assumption of the Natural Lawyers that there is something called Law, with a capital "L". Artifactualists reject this assumption. Rather, they argue that all we have is a system of socially constructed and coercively enforced norms - laws, in the plural and with a small "I" - and these laws are in many ways ad hoc and contingent. In other words, law, if the term is used at all, is only a short hand way of describing an extremely complex matrix of social forces.

Through these claims, Artifactualism builds upon the insights of Realism. However, Artifactualists criticize Realism as being too individualistic in its analyses and insufficiently sensitive to the constitutive dimension of law. To elaborate: Artifactualists agree with the Realists that we must focus not on what judges say they do, but upon what they actually do. But Artifactualists claim that Realists exclude certain structural commonalities of the judiciary as, for example, their homogeneity in terms of class, race and gender. Moreover, Artifactualism posits that law is best understood as the complex product of a host of interacting social forces. Our legal system reflects and condenses these politically significant forces in juridically specific ways, while at the same time, helping to entrench and enforce them as societal norms. Artifactualists understand laws to be socially situated; laws are both reactive to and constitutive of the broader society in which they operate. More specifically, Artifactualists emphasize that law is about power; that it is not only a reflection of the power relations in our society, but that it simultaneously constitutes and legitimizes those power relations. Power is seen as relational because it is negotiated (although unequally) between the different communities in a society. For the Artifactualist, law is not simply perceived as an instrument of the power elites of modern society - although it reflects and supports their interests to a significant degree - but rather, it is conceptualized as a terrain of struggle over the meaning and quality of societal existence.

Despite these profoundly diverse jurisprudential perspectives, one can map out a trail, overgrown and twisted much of the time, that suggests that the route has been one of what might be called "denaturalization", that we have been gradually coming to realize that law has no transhistorical, a priori or universal qualities. Law has no natural essence. It is merely a human construct. Even more importantly, Artifactualism signals a sort of jurisprudential gestalt. ${ }^{10}$ Historically, the paradigm through which jurisprudential inquiry has been conceptualized is the law/morality framework. This approach, I would suggest, has now been decentred so that the currently predominant paradigm is that of law/politics. Artifactualism asks us to recognize that law is deeply embedded in, and constitutive of, 
the larger power dynamics of contemporary society; that law is about particular choices made by particular people in specific contexts; and that law can be used either to reinforce disadvantage or to challenge it. Coming to terms with the denaturalization of law, I would argue, is not a slide into relativism or nihilism, because its focus on the pasted-together nature of law, while sensitive to structural forces and constraints, it valorizes human agency. It also makes us responsible for our legal system, and in particular, its warts.

In the next section, building on the rethinking engendered by the theory of Artifactualism, I will provide the contours for a variety of jurisprudential perspectives that are premised upon this theory, perspectives that - with the exception of Liberalism highlight the problematic nature of contemporary Canadian law. These perspectives are: Liberalism, Marxism, Feminism, First Nations and Critical Legal Studies.

\section{ARTIFACTUALISM AND THE PERSPECTIVES}

Having identified the jurisprudential gestalt from debates that focused on the interaction between law and morality to those that focus on the nexus between law and power, we are now in a position to review some of the currently emerging perspectives and analyze the extent to which each fits with the concept of Artifactualism.

\section{A. LIBERALISM}

Liberal jurisprudence is the dominant mindframe of most legal thinkers - and practitioners - in Canada. In common with most jurisprudential perspectives, Liberal legal theory is premised upon a series of background assumptions, a broader political philosophy. As a result, it is necessary to indicate this background theory as it underpins so much of what is sometimes called "Liberal Legalism". ${ }^{11}$ In recent years, some Liberal thinkers have made much of the claim that Liberalism has no core determinative ideas, that as a political philosophy it is a pluralistic tradition. ${ }^{12}$ However, it seems to me, that

Karl Klare defines "Liberal Legalism" thus:

Liberal legalism is a particular historical incarnation of the legalist outlook, which characteristically serves as the philosophical foundation of the legitimacy of the legal order in capitalist societies. Its essential features are the commitment to general, democratically promulgated rules, the equal treatment of all citizens before the law, and the radical separation of morals, politics, and personality from judicial action. Liberal legalism also consists of a complex of social practices and institutions that complement and elaborate upon its underlying political philosophy and jurisprudence. With respect to its modern Anglo-American form, these include adherence to precedent, separation of the legislative (prospective) and the judicial (retrospective) functions, the obligations to formulate legal rules on a general basis (the notion of ratio decidendi), adherence to complex procedural formalities, and the search for specialized methods of analysis ("legal reasoning"). All of these institutions are designed to serve the fundamental desideratum of separating morals, politics, and personal bias from adjudication.

"Judicial Deradicalization of the Wagner Act and the Origins of Modern Legal Consciousness, 1937. 1941" (1978) 62 Minn. L. Rev. 265 at 276 (footnotes omitted).

12 See, for example, D. Galloway, "Critical Mistakes" in R.F. Devlin, ed., Canadian Perspectives on Legal Theory (Toronto: Emond Montgomery Pub., 1990) 255 [hereinafter Perspectives]. Ted DeCoste has nicely described this as the "hide and seek" version of liberal analysis: F. DeCoste, "Taking A Stand: Theory in the Canadian Legal Academy" (1991) 29 Alta. L. Rev. 941 at 957. 
while there are dangers in unidimensionalizing what is clearly a very diverse political philosophy, there are still certain key aspects that are characteristic of Liberalism.

Liberal political theory has as its starting point an ontology - a theory of being or personhood - that assumes a rational, free-choosing, autonomous self that is prior to, and independent of, both the community and other selves. That is to say, Liberalism takes as its premise an individualized self and upon this foundation constructs a political philosophy and legal theory that is designed to maximize the realm of action that is available to such a self. As a result, Liberal political philosophy argues that society should be governed by the principles of liberty, equality and neutrality. To be more specific, Liberalism advocates that the state and law should strive to provide the citizen with as much space as possible to pursue her own self interests (liberty); that each person should have the equal right to pursue such interests without formal restraints because of their identity, be it on the basis of their race, gender, class or ability (equality); and, that the state should remain agnostic as to the nature of a good life, thereby allowing each individual to determine their own conception of the good as they might choose it in the marketplace of ideas (neutrality).

However, although Liberals consider the self to be ontologically prior to the community, they also recognize that we are social beings and that we live in conditions of interdependence. As a result, they argue that one of the key functions of law is to play a facilitative role, that is, to provide mechanisms for social interaction. For example, contract law has as its primary purpose the aspiration to facilitate the free flow of trade, as that will enable individuals to maximize their wealth and therefore pursue their own conception of the good. But Liberalism also recognizes that each individualized self, in her pursuit of her own privatized conception of the good, may bump into other selves, thereby potentially depriving other selves of the virtues of liberty and equality. Liberalism sees a further purpose of law, as the public manifestation of the communal will, to be the mediation/regulation of these interactions. A second (regulative) function of law then is to determine when one person's actions have a negative impact upon another, and to prohibit such infractions. This is usually called "the harm principle": one cannot use one's own liberty to infringe that of another. In sum, then, as Jamie Cassels points out:

At its best, the function of law is to maximize the autonomy of rational agents in a way that is compatible with the similar autonomy of others and that does not illegitimately prefer any one agent's conception of the good over that of another.

Law is said to be legitimate because it is founded on the consent of the governed, is enacted according to fair rules of participation and procedure, serves to expand autonomy by setting the ground rules for individual and co-operative activity, and is applied by courts acting as neutral arbiters in an impartial and rational fashion. ${ }^{13}$

There are, of course, many variations on this story. For example, a significant debate rages between utilitarian and rights-based (deontological) Liberals. This controversy 
revolves around the question of where to draw the bright line between the individual and the community. Utilitarians tend to give greater weight to the community than to the individual. The classic example is the situation where utilitarians suggest that it may be appropriate to kill one person to save the lives of ten. Deontological Liberals, to the contrary, argue that there are certain basic rights that are so inviolable that they can never be overridden by any collective good. Rights trump. ${ }^{14}$ This tension is embedded in the Canadian Charter of Rights and Freedoms which, on the one hand, espouses a series of seemingly entrenched (deontological) rights, but allows these to be curtailed if to do so would (in a utilitarian sense) be "demonstrably justified in a free and democratic society."

Another important debate centres upon the meaning of equality. Classical Liberals, in support of the principle of state neutrality, tend to espouse a rather formalistic conception of equality: that the state cannot discriminate against anyone on the basis of their identity. More progressive Liberals argue that this is too anaemic a conception of equality and that to counteract past inequalities it may be necessary for the state to take proactive steps to help certain disadvantaged individuals to be able to truly compete. It is these two competing conceptions of equality that underlie debates around issues such as employment equity ${ }^{15}$ and the regulation of pornography. The more substantive approach seems to have gained legitimacy through s. 15(2) of the Charter and, for example, the decision of the Supreme Court in R. v. Butler. ${ }^{16}$

To a significant degree, Liberal Legalism accepts some of the key arguments of Artifactualism. It recognizes that law is, at bottom, a human construct and it attempts to develop rules and principles that will give effect to its preferred principles of individual liberty, freedom, equality and neutrality. However, within this tradition there is a tendency to shy away from a full embracement of Artifactualism in that many Liberals claim that these principles have transcendent or universal qualities that are noncontingent and nonnegotiable. Usually, such claims are based upon some idea of communally agreed upon norms thereby assuming a consensual theory of society. Such consensualism, as will become obvious when we look at other perspectives, is rejected by most Artifactualists.

\section{B. MARXISM}

Marxism is a star example of a jurisprudential perspective that would reject the consensualist assumptions of Liberalism. It points to the pervasiveness of class divisions in Canadian society to argue that our legal norms and system are deeply complicitous in the perpetuation of unequal relations of power. One thing that distinguishes the Canadian legal academy, at least from its American counterparts, is the existence of relatively strong leftist analyses of law. Although the United States, as we shall see, provided the cradle for Critical Legal Studies, that was very much a late 1970s phenomenon, whereas leftism in Canada has had a much more venerable history. In part, this may be due to the political culture of Canada with its social democratic and "red tory" tendencies, but it might also

R. Dworkin, Taking Rights Seriously (London: Duckworth, 1977).

See, for example, J. Fudge \& P. McDermott, Just Wages (Toronto: University of Toronto Press, 1991).

(1992), 89 D.L.R. (4th) 449 (S.C.C.). 
be related to the English connection and the class consciousness of elements of that tradition. Whatever the reason, there exists within Canada a prolific and relatively large collection of jurisprudents who conceive of themselves as left of centre.

Although not all jurisprudents with a left attachment would go as far as describing themselves as Marxists, Marxist legal theory is alive and well and continues to produce critiques of mainstream legal philosophy. Although Marx had some legal education, he never produced a fully developed theory of law. Rather, scholars have extrapolated from his and Engels' many volumes of writings an approximation of what might have been said had he addressed himself to the topic in any systematic way. However, there are a plurality of interpretations of Marx and his tentative reflections on law. Consequently, there is, in fact, no orthodox Marxist theory of law. Having said this, it is suggested that, in spite of the important differences among Marxists, there is consensus that two necessary, though not sufficient, elements must underlie any philosophy of law that considers itself Marxist: a consideration of the relationship between the economy and law, and correlatively, an analysis of the relationship between class and law. Together, these inquiries tend to generate a critique of law from without, to emphasize the connection between law and the power centres of society, and to suggest that law may be more closely related to domination than equality.

As these comments indicate, a Marxist theory of law operates on a very different set of philosophical and ontological assumptions from Liberalism. Rather than taking as its starting point a universalist conception of the individuated and autonomous self, Marxism begins with a theory of history - historical materialism - and then locates its theory of the person, as well as its political and legal theory, within that historical account. History and social circumstances precede and predetermine the self, society, politics and law. Judy Fudge explains historical materialism as follows:

The source of historical change for Marx is the conflict between direct producers (slaves, serfs, or workers) and those who reap the benefit of that production (owners, masters, or employers). This conflict is known as class struggle. Marx's understanding of history is in direct contrast to the Whiggish (liberal) view that dynamic morality and affectivity propel the transformations of history. Central to historical materialism is the concept of mode of production (the organization of productive forces, labour, the instruments and materials of production), which confers a fundamental social unity on a social formation, allocating their objective positions to the classes within it, and distributing agents within it. The mode of production "constitutes the structure which determines what form the growth of the productive forces, and the distribution of the surplus will take, how society can or cannot change its structures, and how at suitable moments, the transition to another mode of production can or will take place." Relations of production are relations of economic power, of the economic power people enjoy or lack over labour power and the means of production. Capitalist productive relations are defined by the separation of the direct producers from the means of production. In order to subsist; workers must sell their services to the owners of property. The owners thus have a monopoly on domination and control over the economic 
surplus. Moreover, they have control over the production process itself, enabling them to organize the labour process in order to extract the maximum amount of effort from their employees. ${ }^{17}$

Law, in this perspective, is a second order social phenomenon, a byproduct of class conflict. For example, Marxists point to the way in which economic relations set the parameters for the operation of legal principles, concepts and rules, claiming that the law tends to facilitate and reinforce relations of class exploitation. In particular, Marxists draw our attention to what they sometimes call the "essential legal relations": property and contract law. Property law is crucial to the establishment and perpetuation of capitalist social relations because the proprietary right constitutes a "private" realm of control, autonomy and exploitation. Contract law is the mechanism by which property is exchanged, that is, where the capacity for exploitation is circulated so that wealth is maximized. These types of law would not necessarily be problematic if we lived in a substantially equal society. But a capitalist society is a structurally unequal society and so property and contract law consolidate and reinforce such inequality by conferring legal right on economic power.

One of the most nefarious examples of this merger of legal right with concepts of property and contract is the employment contract. In this situation, there is an appearance that the employer and the employee are free and equal to enter into a contract where the employer exchanges his property (wages) with the employee's property (labour power). The problem is that this happy picture fails to correlate with reality. First, the employer does not tend to pay the employee for the full value of her labour, that is, employers exploit "surplus labour value" of employees. Second, whereas the employer usually has options as to where and how to invest his money, the employee only has her labour power to sell and usually has extremely limited mobility or job opportunities. Law, therefore, through the employment contract, obfuscates reality and legitimizes exploitation. Moreover, it plays an even more direct role in that it regulates employment relations more generally by, for example, coercing employees when they resist exploitation and through the deradicalization of trade unions by intensive regulation. ${ }^{18}$

Marxists frequently generalize their concerns about property and contract rights to a broader scepticism about rights discourse itself. So, for example, they ask about the "rights" of those who, because of their class position, are the object of state violence through criminalization and incarceration. ${ }^{19}$ Furthermore, they are extremely concerned about the entrenchment of the Charter in that it inculcates and disseminates a societal "rights consciousness" that relocates social activism from the democratic realm to the judicial realm. For example, by highlighting a series of Supreme Court decisions, Marxists argue that this phenomenon of the "legalization of politics"20 has a negative impact on

J. Fudge, "Marx's Theory of History and a Marxist Analysis of Law" in Perspectives, supra note 12 at $151-52$ (references omitted). See R.F. Devlin, "Law's Centaurs: An Inquiry Into The Nature and Relations of Law, State and Violence" (1989) 27 Osgoode Hall L.J. 220. 
the Trade Union movement, which has been very unsuccessful in its appearances in the courts. ${ }^{21}$ For Marxists, law is an unlikely terrain for progressive social transformation.

\section{FEMINISM}

There is something curious about the history of mainstream jurisprudence. In the main, its producers, be they Natural Lawyers, Legal Positivists, Liberals or radicals, have been male; the voices of women have been excluded. On reflection, the absence of women should come as no surprise because legal practice, legal education, the legislatures and the judiciary have all been male dominated. Consequently, the more classical reflections on the meaning, purpose, nature and concept of law have reflected male perceptions and interpretations.

Despite the differences between, for example, Natural Law, Legal Positivism and Liberalism, they all share the assumption that all human beings are at bottom the same, and that sameness of treatment should be the benchmark of legality. Marxism, with its emphasis on the differential impact that law has on class relations, calls into question the idea of the jurisprudence of sameness, and raises the possibility of a jurisprudence of difference. Feminism has taken this viewpoint one step further.

Like many of the other perspectives on contemporary legal theory, there are a diversity of Feminist approaches to jurisprudence; there is no official Feminist line. However, it seems to me that philosophy professor Susan Sherwin has captured the aspiration of Feminism when she argues:

\footnotetext{
Feminism is an awareness of the political and social implications of sex and discrimination within society. It is an awareness that the discrimination facing women is not just a concern about equality among individuals, but is systematic. Feminism is a political commitment to changing the systematic force and values inherent in patriarchy. ${ }^{22}$
}

The first rumblings of Feminist jurisprudence in Canada occurred during the 1970s with the publication of Lorenne Clark's and Debra Lewis' Rape: The Price of Coercive Sexuality. ${ }^{23}$ The basic thesis of this book was that the law of rape was not conceptualized as a violation of women, indeed even as a form of gender specific violence, but rather as a property crime against the capitalistic ownership rights of men. Since then, there has been a proliferation of Feminist analyses of law which, for heuristic purposes, we might break down into the subcategories of liberal, integrative, radical, socialist and raceconscious Feminisms. ${ }^{24}$

J. Bakan, "Constitutional Interpretation and Social Change: You Can't Always Get What You Want (Nor What You Need)" in Perspectives, supra note 11 at 445.

As quoted in C. Boyle, "Book Review: R.J. Sharpe, Imjunctions and Specific Performance (1983); S.M. Waddams, The Law of Damages (1983)" (1985) 63 Can. Bar Rev. 427 at 429 n. 4.

(Toronto: Women's Press, 1977).

This breakdown and overview draws upon the excellent essay by S. Boyd \& E. Sheehy, "Feminist Perspectives on Law: Canadian Theory and Practice" (1986) 2 C.J.W.L. 1. See also, their very helpful annotated bibliography, Canadian Feminist Perspectives on Law (Toronto: Ontario Institute for Studies in Education, 1989). I have supplemented race conscious feminism as an additional approach. 
Liberal Feminism was the first major wave of Feminist legal theory, protesting against women's exclusion from the practice and paradigms of the legal system. The analysis primarily focused on the harm to women as individuals of a discriminatory legal system and sought remedies through the assertion of individual rights. This led to calls for the creation of gender neutral rules, equal opportunity to participate in the legal system, and equal benefit of the law. The assumption underlying liberal Feminism was that the basic structure of Canadian society was essentially fair and all that was needed were some modifications so that women could be treated the same as men. This is sometimes described as an "add women and stir feminism."

A recognition of the limitations of this perspective led to the emergence of what has become known as integrative Feminism. Those who support this perspective argue that the assumption of sameness that underlies liberal Feminism sells Feminist analysis, and therefore women as a class, short. Integrative Feminists argue that a sameness approach is flawed in that it retains men as the benchmark of value and fails to recognize the specificity and differences of women's lives. Integrative Feminism therefore rejects the assumption that the basic structure of Canadian society is essentially fair, and argues for significant social restructuring.

More specifically, integrative Feminists argue that formal equality, gender neutrality and equal opportunity projects (though an improvement) do not go far enough. They advocate what they call "substantive equality" or "equality of results", because, if achieved, this would mean that women could be in a position of existential equality so as to pursue their own goals. Pushing this analysis to its contextual conclusion, integrative Feminists posit that, given women's unequal social status, it will be necessary to treat women differently in order to achieve equality. Hence they advocate for employment equity and gender specific legal norms such as the defence of the "battered woman syndrome" as adopted in $R$. v. Lavallee. ${ }^{25}$ Moreover, integrative Feminists analyze the values that underlie many of our social structures and legal practices and argue that such values are masculine and propose that we need to imbue the system with more "gynocentric" values. ${ }^{26}$

This critique of "malestream" perspectives and the move to a focus on women's perspective as a class is adopted and developed by radical Feminists. Radical Feminists argue that our legal structure is grounded in maleness, not only in form but also in substance. In particular, they argue that the relationship between men and women in contemporary "patriarchal" society more closely approximates domination than equality. Patriarchy is identified as a systematic social practice that determines our public and private lives, the economy, our social interactions, modern culture, state policies and the legal system. Specifically, radical Feminist jurisprudents tend to focus their attention on violence against women and argue that violence is the logical extension of a male supremacism that also manifests itself in our laws relating to, inter alia, employment, reproduction, sexual harassment and pornography.

26 A. Miles, "Feminism, Equality and Liberation" (1985) 1 C.J.W.L. 42. 
Socialist Feminists agree with radical Feminists that sexuality is a major source of women's oppression and that our legal system assists in reinforcing and perpetuating women's subordination. However, they also argue that there is another factor that complicates the analysis of women's subordination: class. While women on one level share the commonality of gender, they are differently affected by their class position. In this approach, gender and class are seen to be equally crucial in understanding women's oppression because depending upon different stages of a capitalist society there may be different forms of patriarchal oppression. Hence, abortion law is often a focus of socialist Feminist analysis. ${ }^{27}$ Additionally, argue socialist Feminists, this awareness of class situatedness and historical contingency is crucial in determining what sort of strategies women might pursue in their resistances to male domination.

Finally, race conscious Feminists claim that the picture of women's subordination is even more complex than even radical or Socialist Feminists suggest. Interlocking with the analytic variables of gender and class is the dynamic of racism. ${ }^{28}$ As women of colour and First Nations women have argued, women's identities cannot be understood as unidimensional. Rather, there are a multitude of social forces structuring women's experiences and that multiple (and even multidimensional) strategies need to be developed in order to deal with these differentiated aspects of their reality. Family law issues are particularly identified as a problematic area where these complexities manifest themselves. ${ }^{29}$

In sum, Feminist analyses of contemporary society and modern law reject completely the suggestion that there is anything consensual, neutral, objective or supra-political about law. For them, it is clear that law is but a holograph of the patriarchal imagination and that that imagination has constructed a reality that is deeply antithetical to women's equality. Reconstructive programs will require both the vision and will power to recognize the depth of the oppression, and to take remedial steps that will factor in the diversity of women's experiences.

\section{FIRST NATIONS}

A central aspect of Artifactualistic analyses is to interrogate and render contingent those perspectives that are so entrenched that they are automatically taken to be incontrovertible. The ambition is not so much to prove that those perspectives are wrong - although that is frequently a byproduct of these critical processes - but to demonstrate that they are partial in their accounts. And "partial" is utilized in both senses, as meaning both incomplete and partisan. The aspiration is that by decentering and denaturalizing the dominant interpretation, there will be space for the emergence of alternative, hitherto subjugated, perspectives. 
Marxism and Feminism, as we have seen, dovetail quite nicely with this Artifactualist paradigm. So, too, does First Nations' jurisprudence. Traditionally in Canada, the dominant jurisprudential assumption has been that the white legal structures - be they common law or civil law - should be determinative of our legal system. It has been presumed that the juridical structures and norms of both of these traditions, premised as they are on the "advanced" legal traditions of Britain and France (Britain with the Rule of Law, and France with its Rights of Man (sic)) are necessarily superior to the indigenous legal norms - if any - of the "primitive" native culture. White law, like white religion, had a salvationist agenda. Moreover, these imperialist assumptions corresponded with the conception that law is the embodiment of universalist principles which, by definition, had to be necessarily common across Canada. ${ }^{30}$

So powerful has this juridical hegemony been that it is only very recently that First Nations jurisprudence even surfaced as a voice in the jurisprudential conversation. While Aboriginal peoples have always had a sense of their own legal norms and structures, in spite of legal colonialism, it is only recently that they have managed to intervene effectively in Canadian jurisprudential debates. But their intervention demonstrates, in a profoundly dramatic way, the political dimensions of law and, more particularly, the harm of law. ${ }^{31}$

The first stage of First Nations' jurisprudence was reactive and focused on the coercive dimensions of law. More specifically, it was argued that law had been used to dispossess Aboriginal peoples of their lands through the conceptualization of treaties as enforceable contracts with sufficient consideration, or that the Indian $\mathrm{Act}^{32}$ and the reserve system disenfranchised and marginalized First Nations peoples, making them dependent wards of the state. Hence the embarrassing, or perhaps more accurately shameful, suggestion that when South Africa was establishing its structure of apartheid, it was inspired in part by Canada's system of reserves. More recently, a great deal of attention has focused on the way in which the criminal justice system of Canada has been not merely discriminatory in its treatment of First Nations people, but actively racist. It is in this light that we can understand not just the high profile inquiries, such as the Marshall Inquiry, ${ }^{33}$ but the everyday normalized racism of police, judicial and prison practices that operate as a conveyor belt to incarcerate huge proportions of the First Nations' communities. ${ }^{34}$ Moreover, it has been demonstrated that it is not just the criminal process that is implicated in Canadian racism, but also custody law ${ }^{35}$ and legal education. ${ }^{36}$

Much is made of the diversity of the legal cultures of the common law and civilian law traditions. While there are important differences, it seems to me that these differences are more of method and process rather than substance, at least when they are both compared to "aboriginal" legal cultures. For a very helpful bibliography, see L. Fritz, Native Law Bibliography, 2d ed. (Saskatoon: University of Saskatchewan, Native Law Centre, 1990).

R.S.C. 1985 , c. I-5.

Nova Scotia, Royal Commission on the Donald Marshall Prosecution (Nova Scotia: Queen's Printer, 1989) (Chair: A.T. Hickman).

See for example, M. Jackson, Locking Up Natives in Canada (Vancouver: Canadian Bar Assoc., 1988).

Supra note 28. 
Indeed, First Nations jurists have pushed their critiques so far that they have begun to articulate the contours of a reconstructive program. While Marxists and Feminists have been extremely critical of law and have called for significant transformations of our legal system so as to be less oppressive and more inclusive of those who have been subordinated, their assumption is still essentially integrationist: they seek to have their perspectives incorporated within a (dramatically) reconstructed version of the prevailing legal system. There is some sense of continuity. This is not true of First Nations' claims. Espousing what might be called a radical jurisprudence of difference, they argue that the current Canadian legal order is so profoundly incompatible with First Nations' cultures that separation is required. So, for example, they argue that the assumptions of the Charter - the supremacy of God and the rule of law - as well as the hegemonic discourse of legal rights, are culturally specific (i.e. Eurocentric) and therefore, alien to Aboriginal forms of social interaction, ${ }^{37}$ which place greater emphasis on duty, respect and responsibility. ${ }^{38}$

Consequently, the emergence of a First Nations' jurisprudence heralds an Artifactualist crisis for mainstream Canadian legal thought. All along it has been assumed that with suitable reupholstering, the legal system could incorporate and therefore deradicalize the perspectives of those who have been excluded. To some extent, that has been achieved with the working classes through collective bargaining, and with women through the constitutionalization of equality provisions. Aboriginal jurists, angered by the way in which the legal system played a crucial and active role in their subordination and marginalization, consider the dominant legal culture to be irretrievably antithetical to their interests and therefore unsalvageable. Thus, their calls for self determination and separate criminal justice systems indicate a profound shift from a legal philosophy that was premised upon an assumption of unity and sameness, to a legal philosophy that asserts the necessity for the acknowledgement of difference and the embracing of radical heterodoxy.

\section{E. CRITICAL LEGAL STUDIES}

Critical Legal Studies takes the idea of Artifactualism to its fullest extent, though it tends to be somewhat less existentially grounded than some of the more politically specific jurisprudential perspectives, such as Feminism or First Nations' jurisprudence.

Critical Legal Studies is more of an American phenomenon than it is Canadian. As I suggested earlier, Critical Legal Studies emerged in the United States because of the historical absence of a left legal academy, whereas in Canada there has been a stronger leftist (Marxist/socialist) tradition. But there are a group of scholars who work in Canada and who see themselves as critical legal theorists. The distinctive characteristic of such scholars are that: (a) they are self-consciously transdisciplinary, in the sense that they

P. Monture, "Ka-nin-geh-heh-gah-e-sa-nonh-yah-gah" (1986) 2 C.J.W.L. 158; and "Reflecting On Flint Woman" in Perspectives, supra note 12 at 351.

M.E. Turpel, "Aboriginal Peoples and the Canadian Charter: Interpretive Monopolies, Cultural Differences" in Perspectives, ibid. at 503.

R. Kapashesit \& M. Klippenstein, "Aboriginal Group Rights and Environmental Protection" (1991) 36 McGill L.J. 925. 
believe that insights from other disciplines can help us to better understand law; (b) that they draw particularly heavily on leftist European theory, particularly in its German and French forms; and (c) that they attempt to be integrative in their critical analyses of law, in that they seek to demonstrate how the dominating impulses of law are pervasive and systemic and therefore manifest in terms of gender, race and class oppression. ${ }^{39}$

Critical Legal Studies makes a conscious effort to deny as many of the arguments, techniques and presuppositions of traditional legal theory as it possibly can. In particular, it argues that an understanding of law cannot be divorced from an understanding of the social context of law, and therefore posits that a jurisprudence must be closely tied to some larger social theory. This leads most critical theorists to argue that law is merely a form of politics and thus drives them to inquire not only as to the ways in which law both expresses and encodes its politics, but also to the way in which law constructs the broader politics of Canada. So, for example, a key argument of critical legal scholars is that law is not just a "reflection" of larger social forces, but is actually constitutive of our social and political relations. This thesis as to the formative role of law is manifested, for example, in critical concerns about the way in which the espousal of Charter claims confers greater authority to an unelected judiciary, and thereby undercuts not merely democratic institutions such as Parliament, but also induces a discourse of rights that may be excessively individualistic. ${ }^{40}$

The aspiration of Critical Legal Studies is both to annunciate and denunciate, and its emphasis has been on the latter. In particular, Critical Legal Studies focus on what it calls "Liberalism", but it is a broad conception of Liberalism that goes beyond that of the differing political parties, to a conception of Liberalism as a politico-philosophical worldview that has dominated our consciousness since the Enlightenment. Drawing on the insights of a variety of perspectives including neo-marxism, structuralism, phenomenology, poststructuralism, deconstructive literary criticism, and critical theory, "Crits" posit that Liberalism is an ideological mindframe that is premised upon the excessive priorization of the individualized conception of the person. The concern is that this ontological fetishization of the individual (to coin a phrase) fails to appreciate fully the ways in which the individual is the product of the social forces that inscribe her personality. Worse still, the priorization of the individual is entrenched by the tendency of law to constitute and enforce legal rights. The effect of this is twofold: first, it tends to insulate those who have power from challenges by those who are dispossessed; second, it reinforces the ideology of individualism and thereby undercuts our communal aspirations. In short, Crits argue that Liberalism, despite its best intentions, is an apology for, and legitimization of, the continued inequality and subordination that is a pervasive aspect of North Atlantic societies, be it on the basis of gender, class or race.

Critical Legal Studies focuses particular attention on the role of the judiciary and even more specifically on the politics of judicial method. Not only does it concur with

Most of those who subscribe to the critical perspective tend to be white males and therefore are not as immediately affected by the structural aspects of domination as, for example, women or people of colour.

See, for example, A.C. Hutchinson, Dwelling on the Threshold (Toronto: Carswell, 1988). 
Marxists, Feminists and race-conscious scholars that judges as a group are an unrepresentative and unsympathetic elite, but it also argues that legal method itself is a profound part of the problem. To elaborate, Crits argue that judges recognize that their role is necessarily political and that this causes a legitimation crisis because they are unelected. The judicial responses, not necessarily conscious or conspiratorial, are twofold. The first is to reify the judicial process, for example, by talking about "The Court", as opposed to particular judges, and by the introduction of a whole series of hierarchical rituals that attempt to put the judge beyond reproach. ${ }^{41}$ The second strategy of denial and legitimation is the judicial tendency to invoke legal precedent and rules to claim that they have little or no choice, by protesting that their hands are tied, and that they are simply applying the law. Drawing on the techniques of deconstructive literary criticism, Crits argue that there is no such thing as determinative rules in a strong sense. This is sometimes called "the indeterminacy thesis" and it posits that for every rule there is a counter rule or an exception, that for every principle there is a counter principle, and that for every policy there is a countervailing policy. In short, the critical proposition is that the judiciary have a great deal more scope for choice than they are willing to admit, and so they are forced into accepting personal responsibility for the political significance of the decisions they make. Objectivity and impartiality — those pseudo-legitimizing criteria for judicial office - are unattainable. All judicial decision-making is political decisionmaking.

The positive dimension of the critical agenda is that, in having demystified both the legal system and legal method, we can then candidly recognize that law is about power and thereby hold these powerbrokers accountable for their practices. Second, Crits call into question the very identity of those who make the law and ask by what authority, or perhaps more accurately by what authoritarianism, do they presume to enforce their worldview on others? Third, Critical Legal Studies demands a greater articulation and justification of reasons for decisions beyond the superficial references to precedent. Specifically Crits call for an open acknowledgement of the political presuppositions upon which the judgments are founded. Fourth, they call for greater representation of those who have been oppressed by and marginalized in the decision-making processes, be they judicial or democratic. And finally, Critical Legal Studies does not back away from the proposition that law is politics because it does not believe that it is possible to avoid power relations. Law is power and power is real, and so, the Crits say, let us admit that and proceed to minimize the power differentials that are so pervasive in Canadian society.

Crits, like every other perspective, are subject to criticism. First, they are accused of "theoreticism", that is, using lots of fancy European theory, but incapable of suggesting practical solutions. Second, they are accused of being too cynical about law and rights, and that if they would only get out of their ivory tower, they would see that if you are at the bottom of the social hierarchy, law is more ambiguous. While law and rights are not everything, they are not nothing either. Third, Crits are pilloried as nihilists, as advocates of the absence of regulative social standards by which to evaluate social conduct, and therefore dangerous. Each of these criticisms has been the subject of extensive and 
ongoing debate among Crits themselves, and while significant differences remain, the common sentiment seems to be that an awareness of such dangers is preferable to an uncritical blind faith in a legal system that is complicitous in the perpetuation of domination and subordination.

\section{CONCLUSION}

Over the years, much has been made of the proposition that Canadians have had an impoverished jurisprudence. ${ }^{42}$ In this short essay, I have attempted to suggest that this is no longer the case. By briefly drawing on the metaphor of a topography, I have posited that the switch from the cartography of law and morality to the cartography of law and politics provides us a map that is more vivid, more detailed and more interesting. Indeed, I would conjecture further that, within the Canadian legal academy, there is a rapid increase in the number of people whose primary interest is in legal theory ${ }^{43}$ and that this interest is engendered in large part by a recognition that both our legal system and the very idea of law itself are in serious trouble. This is a phenomenon that is not unique to the Canadian legal academy, or even law. There is an increasing sense within many disciplines that important technological, political, social, economic and intellectual transitions are underway and that these will destabilize and reconfigure our daily practices. Law, I would suggest, is not immune from these transitions and legal theory is beginning to articulate the significance of these dynamics. It is a hope of this essay that those in legal practice will take heed of these transitions - and respond in a reflective, inclusive and imaginative manner.

See, for example, M. Cohen, "The Condition of Legal Education in Canada" (1950) 28 Can. Bar Rev. 267; F.R. Scolt, "Report of Committee on Legal Research" (1956) 34 Can. Bar Rev. 999; M. MacGuigan, Jurisprudence (Toronto: University of Toronto Press, 1966) 652; Report to the S.S.H.R.C. from the Consultative Group on Research and Education in Law, Law and Learning (Ottawa: S.S.H.R.C., 1983). last decade including, for example, the Canadian Journal of Law and Jurisprudence, Canadian Journal of Women and the Law and the Journal of Human Justice. 